\title{
Cell size and basal metabolic rate in hummingbirds
}

\author{
Tamaño celular y tasa metabólica basal en picaflores
}

\author{
JUAN C. OPAZO ${ }^{*}$, MAURICIO SOTO-GAMBOA ${ }^{2}$
}

\& MARÍA JOSÉ FERNÁNDEZ ${ }^{3}$

\footnotetext{
${ }^{1}$ Center for Advanced Studies in Ecology \& Biodiversity, Departamento de Ecología, Facultad de Ciencias Biológicas, Pontificia Universidad Católica de Chile, Santiago 6513677, Chile

${ }^{2}$ Mauricio Soto-Gamboa, Instituto de Zoología, Facultad de Ciencias, Universidad Austral de Chile, Valdivia, Chile ${ }^{3}$ Department of Integrative Biology, University of California, Berkeley, California 94720-3140, USA;

* E-mail for corresponding author: jopazo@genetics.wayne.edu
}

\begin{abstract}
Nucleotypic theory suggests that genome size play indirect roles in determining organismal fitness. Among endotherms this theory has been demonstrated by an inverse correlation between basal metabolic rate (BMR) and genome size. Nonetheless, accumulation of variables, especially for some key groups of endotherms, involved in C-value enigma (e.g., cell size) will fortify this theory. In this sense, hummingbird species are of particular interest because they are an energetic extreme in avian and endotherm evolution. Knowing_that cell size is proportional to C-value, in this study we tested for a relationship between mean corpuscular volume of red blood cells and BMR in four species of hummingbirds ranging from 4 to $20 \mathrm{~g}$. In comparison with other birds, our hummingbird data show higher BMR and the smallest mean corpuscular volumes, thereby providing further support for the nucleotypic theory.
\end{abstract}

Key words: hummingbirds, nucleotypic theory, basal metabolic rate, mean corpuscular volume.

\section{RESUMEN}

La teoría nucleotípica sugiere que el tamaño del genoma juega un rol indirecto en la adecuación biológica, a través de las variables con las que se relaciona. En endotermos esta teoría ha sido demostrada por la relación inversa entre la tasa metabólica basal y el tamaño del genoma. La acumulación de variables, en grupos claves de endotermos, relacionadas con esta problemática (e.g., tamaño celular) son ideales para poner a prueba esta teoría. En este sentido, los picaflores son de particular interés ya que son el extremo energético dentro de los endotermos. Sabiendo que el tamaño celular es proporcional al tamaño del genoma, en este trabajo ponemos a prueba la relación del volumen corpuscular medio y la tasa metabólica basal, e indirectamente el tamaño del genoma, en cuatro especies de picaflores con masas corporales que van desde 4 a $20 \mathrm{~g}$. Los datos de metabolismo mostraron estar dentro de los mayores descritos para aves, asimismo, los tamaños de los eritrocitos fueron los más pequeños dentro de los valores reportados en la literatura, apoyando así lo propuesto por la teoría nucleotípica.

Palabras clave: picaflor, teoría nucleotípica, tasa metabólica basal, tamaño corpuscular medio.

\section{INTRODUCTION}

Interspecific variation of $\mathrm{C}$-value (i.e., defined as the amount of DNA contained in a haploid nucleus) was described decades ago by Mirsky \& Ris (1951). A clear distinction exists between prokaryotic and eukaryotic organisms (Li 1997). Prokaryotes exhibit a 20-fold variation in DNA content, explained by the number of genes; bigger genomes contain more genes. Nevertheless, this argument fails to explain the five orders of magnitude variation in C-value among eukaryotes ( $\mathrm{Li}$ 1997). The general non-correspondence between organismal complexity and genome size has been termed the C-value paradox (Thomas 1971). The discovery of non-coding DNA ended the C-value paradox because the differences between species were explained through different amounts of non-coding DNA. However the end of the paradox marked the beginning of the $\mathrm{C}$-value enigma, where several questions were still left to be answered (Gregory 2001a). 
Despite the unknown functions of noncoding DNA, correlations have been shown between cell and nucleus sizes with genome size (Olmo 1983). Associated with these correlations are the causative links between genome size and some physiological and developmental traits (Gregory 2002a). The latter could be interpreted as a selectionist view for explaining the existence of non-coding DNA.

Two groups of theories have been developed to explain the existence of this "extra" genetic material. The first group contains the mutation pressure theories (i.e. Selfish and Junk), being the simplest ones. These theories explain the phenomenon as the simple accumulation of DNA throughout evolutionary time up to the point where imposed replication costs are no longer sustainable (Ohno 1972, Doolitle \& Sapienza 1980, Orgel \& Crick 1980). The other group, termed optimal DNA theories (i.e., nucleoskeletal and nucleotypic) are based on functionalist views of the problem, proposing coevolutionary and causative explanations, respectively (Commoner 1964, Bennett 1971, 1972, Cavalier-Smith 1978).

Particularly for endothermic organisms (birds and mammals) nucleotypic theory discusses the correlation between cell volume (red blood cells) and genome size, based on differences in basal metabolic rate (BMR) (Gregory 2001b). In fact, a marked correlation exists between BMR and genome size in mammals and birds (Vinogradov 1995, Gregory 2002b, Waltari \& Edwards 2002, Kozlowski et al. 2003). The connection between red blood cell volume and BMR is based on the hypothesis that higher metabolic demands in endotherms require more efficient systems to supply oxygen to metabolically active tissues (associated with the surface area:volume ratio). Accordingly, among endotherms, birds exhibit higher mass specific BMR and smaller genome sizes than mammals (Gregory 2002b).

More functionalist evidence can be found within the mammals. Species belonging to the order Chiroptera (bats) developed flight ability in a manner functionally similar to birds. Therefore, like birds, bats require higher metabolic rates and more efficient gas transport systems than non-volant mammals. In agreement with the nucleotypic explanation, bats have higher BMR than other mammals (McNab 1969) and smaller genome sizes than non-volant mammals (Burton et al. 1989). Within birds, Hughes (1999) reported a direct test of metabolism as a selective agent for genome size. In his study, bird families were classified into four categories according to their flight abilities (strong fliers, moderate fliers, weak fliers and flightless), and then this classification was correlated with genome size. The results showed that genome size increased as flight ability was lost, suggesting that flight ability is not randomly associated with genome size.

In this framework, data on mean corpuscular volume and basal metabolic rate of hummingbirds represent an important contribution to this debate because their small size (they are among the smallest of endothermic vertebrates) and the high cost of hovering flight make them an energetic extreme in avian evolution (Suárez 1992, Fernández et al. 2002, López-Calleja \& Bozinovic 2003). Indeed, the mean body mass of hummingbirds is approximately $5 \mathrm{~g}$, with the exception of the giant hummingbird (Patagona gigas), which at $20 \mathrm{~g}$ appears as an outlier in the distribution of hummingbird body sizes. Consequently, in this work we report the mean corpuscular volume of red-blood cells and basal metabolic rate in four species of hummingbirds, including the giant one.

\section{MATERIAL AND METHODS}

We captured five individuals of Rhodopis vesper in Arica $\left(18^{\circ} 29^{\prime} \mathrm{S}, 70^{\circ} 19^{\prime} \mathrm{W}\right)$, five Oreotrochilus estella in Chusmiza $\left(19^{\circ} 40^{\prime} \mathrm{S}\right.$, $\left.69^{\circ} 10^{\prime} \mathrm{W}\right)$, three Sephanoides sephaniodes in San Carlos de Apoquindo (33 ${ }^{\circ} 3^{\prime} \mathrm{S}, 70^{\circ} 31^{\prime}$ $\mathrm{W})$, and four individuals of Patagona gigas in El Pangue ( $\left.33^{\circ} 31^{\prime} \mathrm{S}, 70^{\circ} 50^{\prime} \mathrm{W}\right)$.

Mean corpuscular volume was measured in an automated hematology analyzer (Sysmex KX-21N, Roche) from a blood sample. Measurements of basal metabolic rate (BMR) were made on adults within thermoneutrality $\left(30 \pm 0.5^{\circ} \mathrm{C}\right)$, at night in a $1,000 \mathrm{~mL}$ steel dark metabolic chambers while animals were resting, inactive and post-absorptive. BMR was measured in a computerized (Datacan V) openflow respirometry system (Sable Systems, Henderson, Nevada). The metabolic chamber received dried air at a rate of $550 \mathrm{ml} / \mathrm{min}$ from mass flow controllers (Sierra Instruments, 
Monterey, California). Air passed through $\mathrm{CO}_{2-}$ absorbent granules of Baralyme and Drierite before and after passing through the chamber, and was monitored every $5 \mathrm{~s}$ by an Applied Electrochemistry $\mathrm{O}_{2}$-analyzer, model S-3A/I (Ametek, Pittsburgh, Pennsylvania). Oxygen consumption $\left(\mathrm{VO}_{2}\right)$ values were calculated using equation 4a of Withers (1977). Each $\mathrm{VO}_{2}$ trial was completed between 21:00 and 02:00 h. Body mass was measured prior to metabolic measurements using an electronic balance $( \pm$ $0.1 \mathrm{~g}$ ). For each measurement period, we used only the last $2 \mathrm{~h}$ of recordings. The initial period was not considered in the analysis because of potential variance due to handling disturbance. We selected the lowest $\mathrm{VO}_{2}$ values lasting at least $3 \mathrm{~min}$, during which $\mathrm{VO}_{2}$ did not change more than $0.01 \%$ in $\mathrm{O}_{2}$ concentration.

\section{RESULTS AND DISCUSSION}

Results are summarized in Table 1. BMR values for the hummingbird species measured in this study follow the classic allometric relationship described for endotherms $(\mathrm{R}=-0.74, \mathrm{P}<0.001)$ (Fig. 1A), in other words, smaller hummingbirds have higher mass specific metabolic rates than bigger ones. In addition, among birds hummingbirds are in the extreme of the curve (Fig. 1B). Mean corpuscular volume (MCV) measurements are the smallest so far among 204 bird species reported from 19 orders (Hawkey et al. 1991). However there are no data yet from other hummingbird species (Hawkey et al. 1991). MCV has a clearer connection with metabolic rate, since smaller cells have greater surface area per unit of volume, making gas exchange more efficient. In short, our data showed higher BMR values and the smallest mean corpuscular volumes among birds, in other words, higher metabolic demands and the highest SA: V relationship.

Unfortunately, we can not compare our data within the genome and erythrocyte size relationship published by Gregory (2002b), because, contrarily to us, his data are linear measurement. Nevertheless, since the mean corpuscular volume (MCV) of hummingbirds are the smallest among birds, in agreement with the relationship of $\mathrm{MCV}$ and genome size (Gregory 2002b) is possible to predict that hummingbirds would have the smallest genome sizes of the group. According to this guess, preliminary data would suggest that hummingbird's genome sizes would be at the left size of the distribution of bird's genome sizes (J.C. Opazo unpublished data). The mechanistic basis of genome size change is important if we think that in mammals as much as $20 \%$ of the variance of metabolic rate can be attributed to genome size differences (Vinogradov 1995). In this sense, adjustments in genome size could be used to fine tune metabolic rates independent of body mass (Vinogradov 1995). This argument is based on the restricted variation on genome size among endotherms, where not greater changes are allowed (Opazo 2003). In comparison with mammals, bird's genome sizes are smaller and vary between 0.95 to $2.16 \mathrm{pg}$ (Gregory 2001c), and as a general trend would had been the result of an optimization process on variables that are related with genome size (e.g., cell size), being maintained by stabilizing selection (Cavalier-Smith 1978).

TABLE 1

Summary statistics of traits measured in hummingbird species; $\mathrm{n}=$ number of individuals, $\mathrm{M}_{\mathrm{b}}=$ body mass, $\mathrm{BMR}=$ basal metabolic rate, $\mathrm{MCV}=$ mean corpuscular volume of red blood cells. Values are expressed as mean $\pm \mathrm{SD}$

Resumen de las variables medidas en las especies de picaflores; $\mathrm{n}=$ número de individuos, $\mathrm{M}_{\mathrm{b}}=$ masa corporal, $\mathrm{BMR}=$ tasa metabólica basal, MCV = volumen corpuscular medio de los glóbulos rojos. Los valores representan la media \pm DE

\begin{tabular}{lcccc}
\hline Species & $\mathrm{n}$ & $\mathrm{M}_{\mathrm{b}}(\mathrm{g})$ & $\mathrm{BMR}\left(\mathrm{mL} \mathrm{O}_{2} \mathrm{~g}^{-1} \mathrm{~h}^{-1}\right)$ & $\mathrm{MCV}(\mathrm{fl})$ \\
\hline Rodophis vesper & 5 & $4.78 \pm 0.56$ & $4.89 \pm 0.38$ & $99.32 \pm 3.88$ \\
Sephanoides sephaniodes & 3 & $5.32 \pm 0.94$ & $3.68 \pm 0.16$ & $91.43 \pm 1.67$ \\
Oreotrochilus estella & 5 & $7.35 \pm 0.70$ & $3.07 \pm 0.37$ & $98.14 \pm 2.14$ \\
Patagona gigas & 4 & $18.07 \pm 2.29$ & $2.88 \pm 0.24$ & $108.66 \pm 6.06$ \\
\hline
\end{tabular}




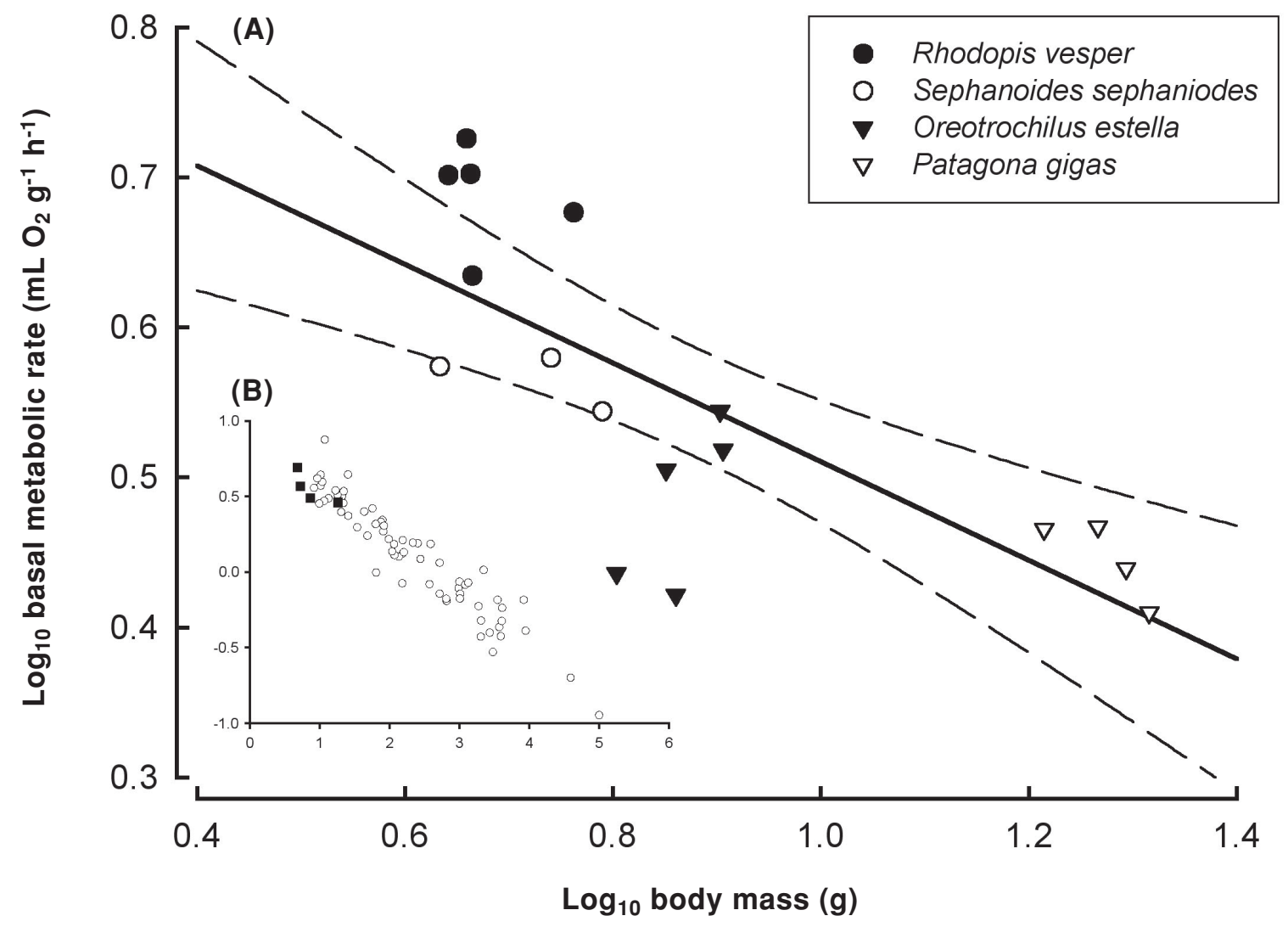

Fig. 1: (A) The relationship between body mass and basal metabolic rate for the hummingbirds used in this study. The continuous line represents a linear regression, and the dotted line indicates the $95 \%$ confidence interval. Each point represents one individual. (B) The relationship between body mass and basal metabolic rate in birds, black squares are the hummingbird species used in this study. Data was obtained from Kozlowski et al. (2003).

(A) Relación entre la masa corporal y la tasa metabólica basal en los picaflores usados en este estudio. La línea continua representa la regresión lineal y la segmentada el intervalo de confianza al $95 \%$. Cada punto representa un individuo. (B) Relación entre la masa corporal y la tasa metabólica basal en aves, los cuadrados negros representan las especies de picaflores usadas en este estudio. Los datos fueron obtenidos de Kozlowski et al. (2003).

In this sense, hummingbirds represent an excellent model for studying the mechanistic basis of genome size change. Some evidence has shown that birds have shorter introns than mammals, suggesting this mode as a mechanism to change the genome size (Hughes \& Hughes 1995). However, Waltary \& Edwards (2002) showed that the $66 \%$ of introns that are shorter in chickens than in humans are also shorter in Alligator missisipensis, a sister taxa of birds, suggesting that the shortage occurred in the ancestor of archosaurs, and then can not be explained merely by the emergence of flight. Another way to change the genome size could be by change the length of repetitive DNA. Birds have been shown to have shorter repetitive sequence motifs than mammals, especially dinucleotide ones (CA and CT), for tri or tetra nucleotide motif differences are smaller (Primmer et al. 1997). These results are in agreement with the data reported for bats. Shorter sequences of microsatellites in bats in comparison with non volant mammals were shown by van de Bussche et al. (1995).

As a whole, our results agree with the functionalist view of the genome size enigma, that is smaller cell sizes for higher metabolic rates. Additionally, since hummingbirds are an extreme in the evolution of endothermy, they represent an ideal model to test mechanistic hypotheses dealing with evolutionary changes in genome size. 


\section{ACKNOWLEDGEMENTS}

This work was founded by FONDAP 1501-001 (program 1) to FB, FONDECYT grant \#3000047 to M. Victoria López-Calleja and CONICYT 2002 fellowships to JCO and MSG. M. Galleguillos and M. Ocqueteau provided support for measurements of cell sizes. M. A. Lardies helped us with field work. R. Finke, M. Konarzewski and E. P. Lessa provided useful comments on early versions of the manuscript. We are particularly grateful to T.R. Gregory for helpful comments on the manuscript and for facilitating access to his database. This paper is dedicated to the memory of Dr. Mario Rosenmann.

\section{LITERATURE CITED}

BENNETT MD (1971) The duration of the meiosis Proceedings of the Royal Society of London B 178: 277-279.

BENNETT MD (1972) Nuclear DNA content and minimum generation time in herbaceous plants. Proceedings of the Royal Society of London B 181: 109-135.

BURTON DW, JW BICKHAM \& HH GENOWAYS (1989) Flow-cytometric analyses of nuclear DNA content in four families of Neotropical bats. Evolution 43: 756-765.

CAVALIER-SMITH T (1978) Nuclear volume control by nucleoskeletal DNA, selection for cell volume and cell growth rate and the solution of the DNA Cvalue paradox. Journal of Cell Science 34: 247-278.

COMMONER B (1964) Roles of deoxyribonucleic acid in inheritance. Nature 202: 960-968.

DOOLITTLE WF \& C SAPIENZA (1980) Selfish genes, the phenotype paradigm and genome evolution. Nature 284: 601-603.

FERNÁNDEZ MJ, MV LÓPEZ-CALLEJA \& F BOZINOVIC (2002) Interplay between the energetics of foraging and thermoregulatory costs in the hummingbird Sephanoides sephaniodes. Journal of Zoology, London 258: 319-326.

GREGORY TR (2001a) Coincidence, coevolution, or causation? DNA content, cell size, and the C-value enigma. Biological Reviews 76: 65-101.

GREGORY TR (2001b) The bigger the C-value, the larger cell: genome size and red blood cell size in vertebrates. Blood Cells, Molecules, and Diseases 27: $830-843$.

GREGORY TR (2001c) Animal genome size database. http://genomesize.com

GREGORY TR (2002a) Genome size and developmental parameters in the homeothermic vertebrates. Genome 45: 833-838.

GREGORY TR (2002b) A bird's-eye view of the C-value enigma: genome size, cell size, and metabolic rate in the Class Aves. Evolution 56: 121-130.
HAWKEY CM, PM BENNETT, SC GASCOYNE, MG HART \& JK KIRKWOOD (1991) Erythrocyte size, number and haemoglobin content in vertebrates. British Journal of Haematology 77: 392-397.

HUGHES AL (1999) Adaptative evolution of genes and genomes. Oxford University Press, Oxford, United Kingdom. 270 pp.

HUGHES AL \& MK HUGHES (1995) Small genomes for better flyers. Nature 377: 391.

KOZLOWSKI J, M KONARZEWSKI \& AT GAWELCZYK (2003) Cell size as a link between noncoding DNA and metabolic rate scaling. Proceedings of the National Academy of Sciences USA 100: 14080-14085.

LI W-H (1997) Molecular evolution. Sinauer Associates Inc., Massachusetts, USA. 487 pp.

LÓPEZ-CALLEJA MV \& F BOZINOVIC (2003) Dynamic energy and time budget in hummingbirds: a study in Sephanoides sephaniodes. Comparative Biochemistry \& Physiology 134:283-295.

McNAB BK (1969) The economics of temperature regulation in Neotropical bats. Comparative Biochemistry and Physiology 31: 227-268.

MIRSKY AE \& H RIS (1951) The desoxyribonucleic acid content of animal cells and its evolutionary significance. Journal of General Physiology 34: 451-462.

OHNO S (1972) So much "junk" DNA in our genome. In: Smith HH (ed) Evolution of genetic systems: 366370. Gordon \& Breach, New York, New York, USA.

OLMO E (1983) Nucleotype and cell size in vertebrates: a review. Basic and Applied Histochemistry 76: 227-256.

OPAZO JC (2003) Genómica functional: el efecto nucleotípico en endotermos. In: Bozinovic F (ed) Fisiología ecológica y evolutiva: teoría y casos de estudio en animales: 45-57. Ediciones Universidad Católica de Chile, Santiago, Chile.

ORGEL LE \& FHC CRICK (1980) Selfish DNA: the ultimate parasite. Nature 284: 604-607.

PRIMMER CR, T RAUDSEPP, BP CHOWDHARY, AP MOLLER \& H ELLEGREN (1997) Low frecuency of microsatellites in the avian genome. Genome Research 7: 471-482.

SUÁREZ RK (1992) Hummingbird flight: sustained the highest mass-specific metabolic rates among vertebrates. Experientia 48: 565-570.

THOMAS CA (1971) The genetic organization of chromosomes. Annual Review in Genetics 5: $237-$ 256.

VAN DE BUSSCHE RA, JL LONGMIRE \& RJ BAKER (1995) How bats achieve small C-values: frequency of repetitive DNA in Macrotus. Mammalian Genome 6: 521-525.

VINOGRADOV AE (1995) Nucleotypic effect in homeotherms: body-mass-corrected basal metabolic rate of mammals is related to genome size. Evolution 49: 1249- 1259

WALTARI E \& SV EDWARDS (2002) Evolutionary dynamics of intron size, genome size, and physiological correlates in archosaurs. American Naturalist 160: 539-552.

WITHERS PC (1977) Measurements of metabolic rate, $\mathrm{VCO}_{2}$, and evaporative water loss with a flow through mask. Journal of Applied Physiology 42: 120-123. 